\title{
SISTEM SEWA MENYEWA RUMAH-RUMAH KOS DALAM PERSPEKTIF HUKUM EKONOMI SYARIAH
}

\author{
Oleh :Muh. Said HM, Syafiah Sukaimi, Arridho Abduh \\ Dosen UIN Sultan Syarif Kasim Riau \\ Email: arridho.abduh@gmail.com \\ Hp/Wa: 081275896529/08127543037
}

\begin{abstract}
Leasing boarding houses in general is one of the word of bussines. Bussines whose development is quite significant in each area of the archipelago, along with existence and development of the higher education it self. Simpang Baru Subdistrict, Tampan district, one of the areas, which in the last 10 years, the existence and development of boarding houses with very high acceleration, in addition to being supported by a very strategic area, also because of the development of various higher education around it. Investors (entrepreneurs) from outside the region also contribute along with the efforts carried out by the local community. The dominant consumerists from aming students from various tertiary instittutions, were greatly helped in utilizing boarding houses ass rental domiciles. The system of renting rented boarding houses so far, between the two parties has traditionally been incidental, has not been bound by a contract with clear rules (written) that containthe obligation and rights between the two parties (the tenat and the rent), so that in the future various risks and losses in the use of boarding houses, only borne by one party where the tenant is always disadvantaged. The system is certainly not suitable from the perspective of Islamic economic Law, although onone side of the socioeconomic impact op people's lives in general it cannot be denied and is quite significant.
\end{abstract}

Keywords: renting system, Sharia economic law.

\section{Abstrak}

Sewa menyewa rumah-rumah kos pada umumnya merupakan salah satu dunia usaha bisnis yang perkembangannya cukup signifikan di setiap daerah Nusantara, seiring dengan keberadaan dan perkembangan Perguruan Tinggi itu sendiri. Kelurahan Simpang Baru Kecamatan Tampan, salah satu daerah diantaranya, yang dalam 10 tahun terakhir ini, keberadaan dan perkembangan bangunan rumah-rumah kos dengan percepatan sangat tinggi, disamping karena didukung oleh wilayah yang sangat strategis, juga karena perkembangan berbagai Perguruan Tinggi disekitarnya. Investor (pengusaha) dari luar daerah turut berkontribusi seiring usaha-usaha yang dilakukan oleh masyarakat (penduduk) setempat. Para konsumeris yang dominan dari kalangan Mahasiswa dari berbagai Perguruan Tinggi, sangat terbantu dalam 
pemanfaat rumah-rumah kos sebagai domisili sewa. Sistem sewa menyewa rumah-rumah kos selama ini, antara kedua belah pihak berjalan secara tradisional insidensial, belum terikat dengan akad dengan aturan-aturan yang jelas (tertulis) yang memuat adanya kewajiban-kewajiban dan hak-hak antara kedua belah pihak (penyewa dan yang menyewa), sehingga bila terjadi dikemudian hari berbagai resiko dan kerugian dalam pemanfatan rumah kos, hanya ditanggung oleh sepihak dimana pihak penyewa yang selalu dirugikan. Sistem tersebut, tentu tidak sesuai dari perspektif hukum ekonomi syariah, meskipun disatu sisi dari dampak sosial ekonomi kehidupan masyarakat pada umumnya tidak dapat dinafikan dan cukup signifikan.

Kata kunci: Sistem Sewa menyewa, Hukum Ekonomi Syariah.

\section{A. Latar Belakang Pemikiran}

Setiap manusia pasti selalu menginginkan kehidupannya di dunia ini agar senantiasa dalam kondisi sosial sejahtera dan bahagia, baik secara material maupun spiritual, individual maupun sosial, sebagaimana halnya substansi dalam doa yang pada umumnya senantiasa dimunajatkan.Oleh karena itu, kesejahteraan dan kebahagiaan merupakan suatu hal yang niscaya diharapkan, merupakan tujuan utama setiap manusia dalam kehidupan. Manusia akan merasa memperoleh kesejahteraan dan kebahagiaan hakiki ketika seluruh kebutuhan dan keinginannyadapat terpenuhi, baik dalam aspek material (jasmani) maupun spiritual (rohani), baik dalam jangka pendek maupun jangka panjang, dunia dan akhirat. ${ }^{1}$

Dalam sistem Hukum Ekonomi Syariah (Fikih Muamalah), sesungguhnya mengangkat nilai berbagai usaha, dan mendorong setiap manusia agar senantiasa mau aktif berusaha (kreatif dan produktif) dengan sungguhsungguh, baik untuk mencapai penghidupan yang layak, dan menghasilkan

\footnotetext{
${ }^{1}$ Kesejahteraan dan kebahagiaan, merupakan bagian dari substansi istilah al-falah dalam al-Qur'an, dalam artian lainnya kesuksesan, kemuliaan dan kemenangan (baca; QS. 3: 104, 7: 8 dan 157, 9: 88, 23: 102 dan QS. 24: 51). Sejahtera diterjemahkan dari kata prosperous yang berarti maju dan sukses, terutama dalam hal pendapatan dan memperoleh kekayaan yang cukup banyak.Sedangkan bahagia (happiness) memiliki makna yang lebih luas, yang berarti kondisi atau perasaan nikmat dan nyaman, yang biasa disebabkan oleh terpenuhinya berbagai kebutuhan material maupun spiritual.Dalam al-Quran, kata atau istilah al-falah, sering dimaknai sebagai keberuntungan jangka panjang, dunia dan akhirat, sehingga tidak hanya aspek material, namun justeru lebih ditekankan pada aspek spiritual.Dalam konteks kehidupan dunia, al-falah mencakup tiga pengertian mendasar, yaitu kelangsungan hidup, kebebasan berkeinginan, serta kekuatan dan kehormatan.Sedangkan dalam konteks untuk kehidupan akhirat, al-falah mencakup pengertian kelangsungan hidup yang abadi, kesejahteraan abadi, kemuliaan abadi, dan pengetahuan abadi atau bebas dari segala kebodohan. Baca; Pusat Pengkajian dan Pengembangan Ekonomi Islam UII Yogyakarta atas kerja sama dengan Bank Indonesia, Ekonomi Islam, edisi 1, Jakarta: PT. Raja Grafindo Persada, 2008, p. 2, dan 50
} 
barang-barang dan jasa yang menjadi keperluan umat manusia, maupun amal yang bersifat ibadah semata-mata kepada Allah. Allah Swt telah melapangkan bumi dan menyediakan banyak sarana dan fasilitas agar setiap manusia dapat berusaha secara maksimal, mencari sebahagian dari rezki yang disediakan-Nya bagi keperluan hidupsemua makhluknya. Maka kesempatan yang ada bagi setiap manusia tidak patut disia-siakan, melainkan harus selalu dipergunakan dengan sebaik mungkin dalam berusaha untuk kepentingan dunia di samping persiapan untuk hari akhirat kelak yang pasti (QS. 28: 77).

Mayoritas ulama fikih (ekonom syari'ah) sepakat akan hukum berusaha (bekerja) adalah merupakan suatu kewajiban dengan segala potensi yang dimiliki, baik dengan melalui pemanfaatan akal pikiran, maupun tenaga fisik. Berusaha atau bekerja, yang jelaspasti memiliki nilai-nilai ekonomis, oleh sebab itu tenaga seseorang pekerja layaknya komoditi yang harus dibeli dengan uang, atau harus dibayar mahal. ${ }^{2}$ Di samping itu, berusaha atau bekerja berarti turut mengaktifkan roda perekonomian masyarakat suatu bangsa, termasuk proses produksi, konsumsi dan distribusi yang berimplikasi secara makro meningkatkan pertumbuhan ekonomi masyarakat dan suatu Negara sekalipun. Sumber daya alamini, mungkin selalu bermurah hati atau berlebih-lebihan dalam menyediakan sumber asli yang tidak ada hadd (batasnya) kepada masyarakat (Negara), tetapi tanpa usaha manusia bekerjasecara aktif, produktif dan profesional, semuanya akan tetap tersimpan tanpa dapat digunakan dan diberdayakan atau dieksploitasi. ${ }^{3}$

Di era dunia global hari ini, seiring dengan semakin pesatnya perkembangan dari berbagai aspeknya, termasuk khususnya dalam hal ini dibidang ekonomi, menunjukkan karena dunia usaha bisnis dari berbagai trendnya semakin pesat pula perkembangannya.Semakin menuntut berbagai usaha bisnis yang harus dilakukan, ketika manusia tidak mau dikatakan sebagai manusia yang tertinggal dalam upaya memenuhi tuntutan kebutuhan hidupnya dalam dunia serba kompetitif ini. Ada sejumlah total usaha yang selama ini dapat dikembangkan lebih lanjut, di antaranya meliputi bidang pertanian, produksi, konstruksi, distribusi, transportasi, komunikasi, usaha jasa, dan pemerintahan yang bergerak dalam bidang membuat sekaligus memasarkan berbagaimacam jenis barang dan jasa ke konsumen.

${ }^{2}$ Ahmad Ibrahim Abu Sin, Manajemen Syariah sebuah Kajian Historis dan Kontemporer, edisi 1, Jakarta: PT. Raja Grafindo Persada, 2008, p. 22-23, bandingkan; Abdul Hamid Mursi, SDM Yang Produktif, Pendekatan al-Quran dan Sains, edisi 1, terjemahan Moh.Nurhakim, Jakarta: Gema Insani Press, 1977, p.iii dan 35

${ }^{3}$ Afzal al-Rahman, Doktrin Ekonomi Islam, Jilid I, edisi 2, terjemahan Mustafa Kassim, Kuala Lumpur: Dewan Bahasa dan Pustaka Kementerian Pendidikan Malaysia, 1994, p. 189 
Sistem sewa menyewa rumah-rumah kos selama ini, antara pihak-pihak pemilik rumah kos dengan dominasikalangan mahasiswi dan mahasiswa sebagai pihak penyewa, pada umumnya belum ada semacam aturan-aturan yang baku, sebagai suatu bentuk perjanjian sewa menyewa yang semestinya,yang dapat diberlakukan di antara masing-masing kedua belah pihak, melainkan dalam hal tersebut hanya dalam bentukkesepahaman dan kesepakatan insidensial, baik untuk dalam jangka waktu sewa bulanan, pertriwulanan, tengah tahunan dan tahunan. ${ }^{4}$ Pada hal di antara kedua belah pihak, masingmasing terhukum oleh adanya hak-hak dan kewajiban-kewajibansecara timbal balik yang pasti, kerena konsekuensi sewa menyewa rumah-rumah kos, cepat atau lambat riskan dengan berbagai problematika atau resiko-resiko krusial yang sangat boleh jadipotensinyaterjadi di kemudian hari.Adalah suatu hal yang tidak mungkin (mustahil) merealisasikan hak-hak dan kewajiban-kewajiban yang melekat pada masing-masing pihak, tanpaterlebih dahulu diikat adanya semacam aturan-aturan atau perjanjian sewa menyewa yang jelas dalam bentuk tertulis yang disepakati, layaknya sebagai persyaratan mutlak dalam sistem sewa menyewa pada umumnya. ${ }^{5}$

Memperhatikan fenomena sistem sewa menyewa rumah-rumah kos tersebut, maka penting artinya untuk lebih lanjut memahaminya melalui tulisan berikut yang merupakan hasil penelitian dalam bentuk penelitian empiris, sehingga pada akhirnya dapat diketahui kejelasan dan kebenaran sistem sewa menyewa rumah-rumah kos dalam perspektif hukum ekonomi syariah.

\section{B. Landasan Teoretis}

\section{Pengertian Sistem Sewa menyewa}

Pada umumnya yang dimaksudkan dengan sistem adalah suatu kesatuan dinamis yang terdiri dari bagian-bagian yang berhubungan secara organik. ${ }^{6}$ Sistem yang bagian-bagiannya yang senantiasa didalamnya berhubungan secara organik tergantung dari kata yang digunakan sebagai rangkaian kata berikutnya yang semestinya dan pada umumnya. Misalnya sistem jaminan sosial, sistem produksi, dan dalam hal ini sistem sewa menyewa. Sementara yang dimaksudkan dengan sewa meyewa, dengan beberapa pengertian berikut ini: Sebutan populer sewa menyewa, berasal dari bahasa arab yang secara bahasanya adalah ijarah yang lazim diartikan: upah, sewa, jasa atau imbalan (al-ajru). Maksudnya imbalan terhadap sesuatu pekerjaan (a-jazau 'alal a'mal)

${ }^{4}$ H. Jarjani (Pemilik Rumah Cost), Wawancara, Selasa, 7 Pebruari 2017

${ }^{5}$ Baca: Ahmad Wardi Muslich, Fiqh Muamalat, edisi 1, Jakarta: Amzah, 2010, p. 471473

${ }^{6}$ Ahmad Ibrahim Abu Sinn, Manajemn Syariah Sebuah Kajian Historis dan Kontemporer, terjemahan Dimyauddin Djuwaini, edisi 1, Jakarta: PT. Raja Grafindo Persada, 2008, p. 29 
dan pahala (tsawab). Dalam bentuk lain, kata ijarah juga bisa dikatakan sebagai nama bagi al-ujrah yang berarti upah atau sewa. Selain itu arti kebahasaan lain dari kata al-ajrutersebut adalah al-'wadh (ganti). ${ }^{7}$ Dalam kajian Hukum Ekonomi Syari'ah (Fiqh Mu'amalah), istilah upah dan sewa, keduanya disebut juga ijarah. Upah ialah berupa imbalan ('iwadh) bagi manfaat yang diterima dari jasa atau pekerjaan pihak lain. Upah disebut juga ijarah pengakuan yang berkaitan dengan orang yang memberikan jasa melalui pekerjaan atau keahliannya meskipun jasa tersebut tidak dirasakan secara langsung pada saat itu. Sedangkan sewa ialah berupa imbalan atau ganti rugi bagi manfaat yang diterima dari satu barang milik pihak lain. Sewa disebut juga al-Ijarah al- 'ain yang berkaitan dengan benda atau barang yang jelas wujudnya dan jelas manfaatnya, misalnya menyewa kendaraan, menyewa rumah dan sebagainya. ${ }^{8}$

Dari sisi pengertian istilah, para ulama berbeda-beda pendapat dan redaksi dalam memberikan definisi tentang Ijarah ini, di antaranyaadalah sebagai berikut:

1. Menurut Hanafiyah bahwa ijarah adalah akad atas manfaat dengan imbalan berupa harta.

2. Menurut Malikiyah bahwa ijarah adalah suatu akad yang memberikan hak milik atas manfaat suatu barang yang mubah untuk masa tertentu dengan imbalan yang bukan berasal dari manfaat.

3. Menurut Syafi'iyah, bahwa akad ijarah adalah suatu akad atas manfaat yang dimaksudkan dan tertentu yang bisa diberikan dan dibolehkan dengan imbalan tertentu.

4. Manurut Syaikh Syihab al-Din dan Syaikh Umairah bahwa yang dimaksud dengan ijarah adalah akad atas manfaat yang diketahui dan disengaja untuk memberi dan membolehkan dengan imbalan yang diketahui ketika itu.

5. Menurut Muhammad al-Syaibani al-Khatib bahwa yang dimaksud dengan ijarah adalah pemilikan manfaat dengan adanya imbalan dan syarat-syarat.

6. Ulama lain juga ada yang menterjemakan bahwa ijarah (sewa-menyewa) artinya melakukan akad (transaksi) mengambil manfaat sesuatu yang

${ }^{7}$ Fathurrahman Djamil, Penerapan Hukum Perjanjian Dalam Transaksi di Lembaga K euangan Syari'ah,Jakarta:Sinar Grafika, 2012, p. 150, menunjukkan bahwa ijarah dalam pembahasannya menyangkut tentang sewa-menyewa adalah berhubungan dengan benda, baik benda itu tetap maupun benda itu bergerak, sementara pembahasannya tentang upah-mengupah berhubungan dengan tenaga dan jasa manusia. Intinya ijarah (sewa-menyewa) objek transaksinya adalah barang maupun jasa.

${ }^{8}$ Wira Sutirta, Akad Sewa-menywa (Ijarah) dalam Hukum Islam, Artikel: 02 juli 2008, p. 1, diakses Selasa 7 Maret 2017, pukul 17,25 
diterima dari orang (pihak) lain dengan jalan membayar sesuai dengan perjanjian yang telah dilakukan. ${ }^{9}$

Berbagai pendapat ulama fiqh tersebut, dapat diambil suatu kesimpulan bahwa pada umumnya ijarah dalam artian sewa-menyewa, merupakan suatu akad atas manfaat yang diperbolehkan penggunaannya, yang jelas, yang mempuyai tujuan dan maksud, yang memungkinkan untuk diberikan dengan tidak mengurangi nilai barang (manfaat) yang dipinjam (disewa), dengan pengganti (sewa) yang jelas. Dengan kata lain, suatu transaksi atas manfaat yang mubah dengan jangka waktu yang diketahui dengan kompensasi yang diketahui pula. Atau akad pemindahan hak guna (manfaat) atas suatu barang atau jasa dalam waktu tertentu melalui pembayaran sewa, tanpa diikuti dengan pemindahan kepemilikan barang itu sendiri.

Dengan demikian, secara umum istilah al-ijarah ini dalam sistem sewamenyewa mengharuskan adanya unsur-unsur yang saling berhubungan, meliputi: Mu'ajir dalam hal ini sebagai pengusaha atau majikan, yaitu sebagai pemilik yang menyewakan manfaat, pihak lain yang diberikan sewa disebut sebagai musta'jir(penyewa), dan objek yang disewakan (ma'jur) yaitu sesuatu yang diperjanjikan untuk diambil manfaatnya, serta ujrahatau 'iwadhyaitu upah atau jasa yang diberikan sebagai imbalan manfaat yang diperjanjikan. ${ }^{10}$ Jadi, secara implisit dapat juga dipahami bahwa ada dua macam bentuk ijarah. Pertama, Ijarah atas pekerjaan (ba'i al-Quwwah), yang dimaksudkan berhubungan istilah upah-mengupah, yang objek akadnya adalah jasa, tenaga, amal atau pekerjaan seseorang, misalnya buruh bangunan, tukang jahit dan sebagainya. Kedua, ijarah atas manfaat (ba'i al-Manafi'), yang dimaksudkan berhubungan dengan istilah sewa-menyewa, yang objek akadnya adalah manfaat dari suatu benda. Akad atau transaksi sewa-menyewa dibolehkan atas manfaat yang mubah (dibolehkan), seperti rumah-rumah untuk tempat tinggal, ruko-ruko untuk berbisnis, pakaian danperhiasan untuk dipakai dan sebagainya. Sebaliknya, manfaat yang diharamkan maka tidak boleh disewakan sekaligus tidak boleh mengambil imbalan (sewa) untuk manfaat yang diharamkan, seperti bangkai dan darah misalnya. ${ }^{11}$

\section{Dasar dan Sumber Hukum Sewa Menyewa}

Pada dasarnya al-Ijarah, baik dalam bentuk upah-mengupah maupun dalam bentuk sewa-menyewa dalam hal ini, merupakan bentuk mu'amalahyang

${ }^{9}$ Ahmad Wardi Muslich, Fiqh Muamalat, edisi 1, Jakata: Amzah, 2010, p. 316-317, dan bandingkan; Hendi Suhendi, Fiqh Mu'amalah, Jakarta: PT. Rajawali Press, 2011, p. 114115

${ }^{10}$ Wira Sutirta, Op.cit

${ }^{11}$ Ahmad Wardi Muslich, Op.cit, p. 329-330, dan bandingkan Hendi Suhendi, Loc.cit, p. 115 
telah disyariatkan dalam sistem hukum ekonomi syari'ah. Hukum asalnya menurut jumhur ulama adalah mubah atau boleh bila dilaksanakan sesuai dengan ketentuan yang ditetapkan oleh syara' berdasarkan ayat-ayat al-Quran, hadit-hadits, dan ketetapan ijma ulama, ${ }^{12}$ termasuk dalam hal tersebut berbagai aturan-aturan lainnya.

Adapun dasar-dasar atau sumber hukum tentang kebolehan al-Ijarah ini, yang dapat dipahami secara tekstual maupun secara kontekstual antara lain misalnya sebagai berikut:

a. Firman Allah Swt surah al-Thalaq ayat 6 dan surah al-Baqarah ayat 282, masing-masing yang terjemahannya:

Artinya: Kemudian jika mereka menyusukan (anak-anak)mu untukmu Maka berikanlah kepada mereka upahnya, dan musyawarahkanlah di antara kamu (segala sesuatu) dengan baik; dan jika kamu menemui kesulitan Maka perempuan lain boleh menyusukan (anak itu) untuknya (QS. Al-Thalaq, 65 : 6). Artinya: Hai orang-orang yang beriman, apabila kamu bermu'amalah (Jual beli, hutang piutang dan sewa-menyewa) tidak secara tunai untuk waktu yang ditentukan, hendaklah kamu menuliskannya, dan hendaklah seorang penulis di antara kaтu menuliskannya dengan benar, dan janganlah penulis enggan menuliskannya sebagaimana Allah mengajarkannya, meka hendaklah ia menulis, dan hendaklah orang yang berhutang itu mengimlakkan (apa yang akan ditulis itu), dan hendaklah ia bertakwa kepada Allah Tuhannya, dan janganlah ia mengurangi sedikitpun daripada hutangnya. jika yang berhutang itu orang yang lemah akalnya atau lemah (keadaannya) atau Dia sendiri tidak mampu mengimlakkan, Maka hendaklah walinya mengimlakkan dengan jujur, dan persaksikanlah dengan dua orang saksi dari orang-orang lelaki (di antaramu). Jika tak ada dua oang lelaki, Maka (boleh) seorang lelaki dan dua orang perempuan dari saksi-saksi yang kamu ridhai .... (QS. Al-Baqarah, 2 : 282).

b. Hadits-hadits Rasulullah Saw berikut:

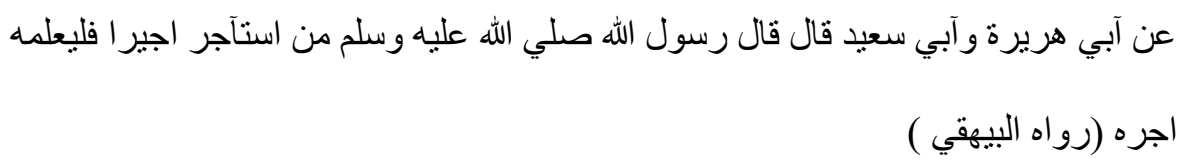

Artinya: Dari Abi Hurairah dan Abi Said berkata, Rasulullah saw bersabda: barang siapa yang mempekerjakan (menyewa sesuatu) seseorang pekerja,

\footnotetext{
${ }^{12}$ Wahbah al-Zuhaily, al-Fiqh al-Islami wa Adillatuhu, Jilid 5, edisi 8, Damaskus: Daar al-Fikr al-Mu'asshim, 2005, p. 801-3802
} 
maka hendaklah ia memberitahukan (dengan jelas) kepadanya berapa bayaran (upahnya atau sewanya) (HR. Baihaqy). ${ }^{13}$

$$
\text { عن عبد الله بن عمر قال قال رسول الله صلي الله عليه وسلم آعطوا الإ جير اجره قبل آن يجف عر قه ( }
$$

Artinya: Dari Abdullah bin 'amar berkata, Rasulullah Saw bersabda berikanlah upahpekerja sebelum kering keringatnya (HR. Ibnu Majah). ${ }^{14}$

c. Landasan Ijma'nya, seperti dikutip Hendi Suhendi dalam kitab Fiqh alSunnah Sayyid Sabiq, bahwa semua umat bersepakat, tak ada seorang ulama pun yang membantah kesepakatan (ijma') ini atas kebolehan melakukan transaksi sewa menyewa (al-Ijarah), sekalipun ada beberapa orang di antara mereka yang berbeda pendapat, akan tetapi hal itu tidak dianggap. ${ }^{15}$

\section{Rukun dan Persyaratan Sewa Menyewa}

Istilah rukun dan syarat dalam sistem hukum ekonomi syari'ah, merupakan dua hal yang harus menjadikan perhatikan dan syarat mutlak, karena sangat menentukan sah tidaknya sesuatu yang dilakukan. Rukun merupakan katentuan yang harus dipenuhi sebelum melakukan pekerjaan. Sebagai sendi atau dasar untuk melakukan sesuatu, atau sebagai sesuatu yang harus dikerjakan dalam memulai suatu pekerjaan, bila tidak terpenuhi, maka pekerjaan menjadi tidak sah. Demikian halnya syarat, merupakan ketentuan atau perbuatan yang harus dipenuhi sebelum melakukan suatu pekerjaan, tanpa memenuhi ketentuan atau perbuatan tersebut, maka suatu pekerjaan dianggap tidak sah juga. Oleh karena itu, rukun dan syarat dalam bermu'amalah menurut syari' at Islam, merupakan suatu hal yang pokok dan urgen yang tidak boleh ditinggalkan.

Khususnya dalam hal ini al-ijarah (sewa-menyewa), menurut Hanafiyah rukunnya hanya satu yaitu ijab dan qabul dari dua belah pihak yang berteransaksi, sementara dari kalangan jumhur ulama, mengatakan bahwa rukun al-ijarah ada empat, yaitu:

1. Dua orang yang berakad (mu'jir; orang yang menyewakan, dan musta'jir; orang yang menyewa)

2. Sighat (ijab dan qabul antara mu'jir dan musta'jir)

3. Sewa atau imbalan (ujrah), dan

${ }^{13}$ Abu Bakar Abdullah Muhammad bin Abi Syaibah, Mushnaf fi al-Hadits wa al-Atsar, Juz IV, edisi 1, Riyadh: Maktabah al-Rusyd, 1409 H, p. 366

${ }^{14}$ Sunan Ibnu Majah, Kitab al-Ruhun, (Bab ajrul ujaraa ), Jerman: Jami'atul Maknazil Islami, 2000, p. 354

${ }^{15}$ Hendi Suhendi, Loc.cit, p. 117 
4. Manfaat (baik manfaat dari suatu barang yang disewa atau jasa dan tenaga orang yang bekerja). ${ }^{16}$

Kemudian, adapun syarat-syarat al-Ijarah, yang pada umumnya sudah menjadi kesepakatan dikalangan ulama fiqh adalah sebagai berikut:

1. Yang terkait dengan dua orang yang berakad, disyaratkan sudah berusia baligh, berakal, cakap mengendalikan harta, dan saling meridhai (QS. 4 : 29). Disamping itu juga, disyaratkan kedua belah pihak mengetahui betul manfaat barang yang diakadkan dengan sempurna, sehingga dapat mencegah terjadinya perselisihan. Kejelasan manfaat itu dapat dilakukan dengan menjelaskan jenis manfaatnya dan penjelasan berapa lama manfaat itu ditangan penyewanya.

2. Sighat ijab qabul antara mu'jir dan musta'jir harus jelas, yaitu ijab qabul sewa menyewa. Misalnya pihak mu'jir berkata; saya sewakan rumah ini dengan sewa Rp. 200.000 perbulannya. Lalu pihak musta'jir menjawab; saya terima sewa rumah tersebut dengan sewa demikian setiap bulannya.

3. Objek al-Ijarah itu boleh diserahkan dan digunakan secara langsung dan tidak ada cacatnya. Bila seseorang misalnya menyewa rumah, maka rumah itu dapat langsung diserahkan (diambil) kuncinya dan dapat langsung boleh ia manfaatkan. Disamping itu, objek al-Ijarah itu adalah merupakan sesuatu yang biasa atau pada umumnya disewakan, sekaligus yang dihalalkan oleh syara'. Oleh sebab itu, para lama fiqh sepakat tidak membolehkan misalnya menyewa seseorang untuk membunuh orang lain, demikian juga tidak boleh menyewakan rumah untuk dijadikan tempat-tempat maksiat.

4. Ujrah (sewa), disyaratkan dalam sewa-menyewa diketahui jumlahnya oleh kedua belah pihak, harus jelas, tertentu, dan sesuatu yang memiliki nilai ekonomi (mal al-Mutaqawwim), atau berupa harga sewa atas manfaat yang disewa. Misalnya Rp.200.000/bulan untuk satu orang, dibayar tunai atau angsuran.

5. Tempat (rumah) yang diambil manfaatnya, harus masih tetap ujudnya sampai batas waktu yang telah ditentukan menurut substansi perjanjian. Demikian pula waktunya harus dapat diketahui dengan jelas dan pasti, misalnya sebulan, pertriwulan, per enam bulan (setengah tahun) atau pertahun. ${ }^{17}$

6. Semua syarat-syarat yang sudah jelas dan terpenuhi serta menjadi kesepakatan oleh kedua belah pihak yang berteransaksi, maka syarat

\footnotetext{
${ }^{16}$ Wahbah al-Zuhaily, Loc.cit, p. 3803, dan bandingkan Ahmad wardi Muslich, Loc.cit, p. 320-321

${ }^{17}$ M. Thalib, Fiqih Nabawi, edisi 2, Surabaya: al-Ikhlas, tt, p. 195
} 
berikutnya yang tidak kalah pentingnya dan harus diupayakan kedua belah pihak adalah semua point-point yang disepakati diwujudkan dalam bentuk tertulis secara resmi sebagaimana layaknya persyaratan dalam teransaksi pada umumnya (QS. $2: 282) .{ }^{18}$

Sedangkan menurut salah seorang ulama dan Guru Besar Universitas al-Azhar Mesir, Syeikh Mahmoud Syaltout dikatakan bahwa bila Islam memberikan hak-hak kepada seseorang untuk mengadakan transaksi berbagai kepentingan, termasuk dalam hal ini sewa menyewa rumah cost misalnya, maka untuk sahnya transaksi tersebut diharuskan paling tidak 3 (tiga) syarat, yakni sebagai berikut:

1. Isi perjanjian tersebut tidak bertentangan dengan pokok-pokok dan syariat Islam secara umum, yang merupakan pokok-pokok kepribadian Islam.

2. Perjanjian tersebut dilakukan berdasakan suka sama suka (keridhaan) dari kedua belah pihak. Oleh karena itu, maka Islam memandang tidak ada harganya suatu perjanjian yang dibuat atas dasar paksaan, dan penaklukan.

3. Perjanjian itu haruslah jelas tujuan dan terang maksudnya, dimana hakhak dan kewajiban-kewajiban masing-masing pihak ditentukan dengan jelas sedemikian rupa, sehingga tidak memungkinkan adanya tafsirantafsiran, adan kesimpulan-kesimpulan lain, atau permainan kata-kata. ${ }^{19}$

\section{Etika Hubungan Mu'jir dan Musta'jir dalam al-Ijarah}

Banyak makna dan arti etika yang dapat dipahami dari kalangan para ahli, karena tergantung sudut pandang dan perspektif mereka yang berbedabeda dalam memahaminya. Namun, dalam hal ini yang dimaksudkan etika adalah dalam artian nilai-nilai yang menjadi pegangan bagi seseorang atau kelompok dalam mengatur tingkah lakunya atau perbuatannya. Dengan kata lain dalam artian bahwa etika adalah asas norma perbuatan atau tingkah laku, tatacara melakukan, sistem prilaku, tata krama, dan sistem aturan atau peraturan-peraturan. Lebih tegasnya lagi dalam hal tersebutlazimnya disebut kode etik. ${ }^{20}$ Misalnya; kode etik hubungan antara mu'jir dan musta'jir dalam hal sewa-menyewa rumah.

Hubungan kode etik antara kedua belah pihak, merupakan keniscayaan dari suatu perjanjian yang dilakukan, yang diharapkan agar masing-masing pihak akan dengan mudah mengetahui sekaligus mentaatinya adanya

\footnotetext{
${ }^{18}$ Baca: Ahmad Wardi Muslich, Loc.cit, p. 320-328, bandingkan, Abdul Rahman Ghazaly, dkk, Loc.cit, p. 278-280, dan Hendi Suhendi, Loc.cit, p.117-118

${ }^{19}$ Syeikh Mahmoud Syatout, Al-Islam 'Aqidah wa Syariah, Jilid IV, terjemahan Bustami A.Gani, dk, Jakarta: Bulan Bintang, 1970, p. 172-173

${ }^{20}$ Baca: M. Yatimin Abdullah, Pengantar Studi Etika, edisi 1, Jakarta: PT. Raja Grafindo Persada, 2006, p. 4-10
} 
kewajiban-kewajiban dan hak-hak masing-masing, sehingga apa yang menjadi substansi dari objek perjanjian dapat berjalan dengan baik, bahkan berkesinambungan, dan kalaupun terjadi perselisihan-perselisihan atau resikoresiko dikemudian hari akan dengan mudah dapat diselesaikan dan diatasi oleh masing-masing pihak. Oleh karena itu, memperjelas dan menentukan hubungan kode etik secara formal adanya kewajiban-kewajiban dan hak-hak masingmasing yang melakukan suatu perjanjian, dalam hal ini sewa-menyewa rumah antara mu'jir (yang menyewakan) dengan murta'jir (penyewa) adalah sesuatu yang seharusnya dan mutlak dalam sistem hukum ekonomi syari'ah.

Dengan terpenuhinya rukun dan syarat-syarat perjanjian al-Ijarah tersebut sebagaimana diutarakan di atas, maka terjadilah hubungan hukum di antara dua pihak, dan dengan sendirinya lahirlah hubungan kewajiban dan hak di antara pihak tersebut. Adapun kewajiban-kewajiban dan hak-hak masing-masing pihak adalah sebagai berikut:

1. Pihak yang menyewakan (mu'jir/mu'ajjir):

a. Ia wajib menyerahkan barang (manfaat rumah) yang disewakan kepada pihak penyewa.

b. Memelihara barang yang disewakan sedemikian sehingga barang itu dapat dipakai untuk keperluan yang dimaksudkan.

c. Memberikan kepada penyewa manfaat atas barang yang disewakan selama waktu berlangsung sewa-menyewa.

d. Menanggung si penyewa terhadap semua cacat dari barang yang disewakan, yang merintangi pemakaian barang.

e. Ia berhak atas barang sewa (imbalan sewa) yang besarnya/jumlahnya sesuai dengan yang telah diperjanjikan atau yang disepakati.

f. Menerima kembali barang objek perjanjian di akhir masa sewa.

2. Pihak penyewa (musta'jir):

a. Ia wajib memakai/memanfaatkan barang yang disewa sebagai bapak rumah yang baik sesuai dengan tujuan yang diberikan pada barang itu menurut perjanjian sewanya, atau jika tidak ada suatu perjanjian mengenai itu, maka menurut tujuan berhubungan dengan itu.

b. Membayar harga/uang sewa pada waktu yang telah ditentukan.

c. Ia berhak menerima manfaat dari barang yang disewanya.

d. Ia menerima ganti kerugian, jika terdapat cacat/rusak pada barang yag disewakan. 
e. Tidak mendapat gangguan dari pihak lain (hak kenyamanan dan ketentraman) selama memanfaatkan barang yang disewa. ${ }^{21}$

Sementara itu yang harus juga menjadikan perhatian bagi masingmasing pihak ketika batas waktu sewa sudah dianggap berakhir bila ada hal-hal sebagai berikut:

1. Objek al-Ijarah musnah, rusak dan hilang sehingga ijarah tidak mungkin untuk diteruskan, seperti rumah yang disewakan kena musibah terbakar, runtuh atau kendaraan yang disewa hilang.

2. Tenggang waktu yang disepakati dalam akad al-Ijarah telah berakhir kecuali kalau ada udzur. Misalnya apabila yang disewakan itu rumah, maka rumah itu dikembalikan kepada pemiliknya. Bilamana rumah yang disewakan disita negara karena terkait adanya utang, maka dalam hal ini akad al-Ijarahnya dianggap batal.

3. Iqalah yaitu pembatalan oleh kedua belah pihak. Hal ini karena al-Ijarah adalah akad mu'awadhah (tukar menukar), harta dengan harta sehingga memungkinkan untuk dilakukan pembatalan seperti halnya jual beli.

4. Wafatnya salah seorang yang berakad. Ini menurut pendapat Hanafiyah.Tetapi menurut pendapat jumhur ulama, kematian salah satu pihak tidak mengakibatkan fasakh atau berakhirnya akad ijarah, karena ijarah merupakanakad yang lazim seperti halnya jual beli, dimana musta'jir memiliki manfaat atas barang yang disewa dengan sekligus sebagai hak milik yang tetap, sehingga bisa berpindah kepada ahli waris. Artinya manfaat itu boleh diwariskan karena termasuk harta (al-Mal), oleh sebab itu kematian salah satu phak yang berakad tidak dianggap membatalkan akad al-Ijarah. ${ }^{22}$

5. Terakhir, jika al-ijarah telah berakhir, penyewa berkewajiban mengembalikan barang sewaan. Bila barang itu dapat dipindahkan (manqul), ia wajib menyerahkan kepada pemiliknya, dan jika bentuk barang sewaan adalah benda tetap (gair manqul), ia wajib meyerahkan kembali dalam keadaan kosong (seperti semula), dan jika barang sewaan itu berupa lahan tanah, ia wajib menyerahkan kepada pemiliknya dalam

${ }^{21}$ Abdul Ghofur Anshori, Hukum Perjanjian Islam di Indonesia, Yogyakarta: Gadjah Mada University Press, 2010, p.73-74, bandingkan: Wira Sutirta, Loc.cit, p. 3-4, bahwa tangan orang yang menyewa (mu'jir/mu'ajjir) adalah tangan yang harus menjaga amanat terhadap rumah yang disewanya pada masa penyewaan, seperti; rumah dan sebagainya. Jika rumah tersebut ada yang rusak (alami) bukan karena kesengajaan atau kelalaian orang yang menyewa, maka dia tidak perlu menggantinya, akan tetapi menurut kesepakatan ulama fikih, jika kerusakan itu kerena kesengajaan atau kelalaian, maka dia wajib membayar ganti rugi atau setidaknya memperbaikinya seperti sedia kala.

${ }^{22}$ Baca: Ahmad Wardi Muslich, Loc.cit, p. 338, dan bandingkan: Abdul Rahman Ghazaly, dkk, Loc.cit, p. 283-284 
keadaan kosong dari tanaman, kecuali bila ada kesulitan untuk menghilangkannya. ${ }^{23}$

\section{C.Sistem Sewa Menyewa Rumah-rumah Kos}

Sepanjang jelajahan peneliti dilapangan, ada beberapa hal yang mendasar sebagai rekaman pemahaman bagi peneliti dalam pelaksanaan sistem sewa-menyewa rumah-rumah kos ini hingga terjadinya kesepahaman dan kesepakatan akhir antara pihak-pihakkonsumeris (mahasiswa-mahasiswi) dan pihak produser(pemilik rumah kos), serta dampak-dampak sosialnya, yaitu sebagai berikut:

\section{Secara Media Sosial dan Sosial Insidensial}

Pada umumnya keberadaan rumah-rumah kos diwilayah Kelurahan Simpang Baru ini dengan mudah dapat diketahui oleh para mahasiswa maupun para calon mahasiswa dan mahasiswi sebagai konsumeris utama. Model rumah-rumah kos kategori lux dan super lux misalnya,sangat lebih mudah dapat diketahui dan dikenal oleh para konsumeris dibandingkan dengan berbagai model rumah-rumah koskategori biasa lainnya. Sebab, tampilan dengan identitas nama yang jelas, juga melalui promosi-promosi sosial, baik melalui media sosial dan elektronik, sebaran brosur-brosur dan tayangan sepanduk, serta sebaran tempelan kertas-kertas photo copi lebih marak dan diutamakan dibandingkan dengan tampilan rumah-rumah kos model-model lainnya, yang hanya lebih mengharapkan dan mengandalkan pengenalanpengenalan secara sosial insidensial dan dari orang perorangan. Dengan sarana identitas komunikasi sosial seperti inilah yang pada akhirnya para konsumeris (calon-calon mahasiswi dan mahasiswa), pada umumnya dapat dengan mudah menemukan, menjatuhkan pinangan danmenentukan pilihan setelah memahami murah-mahalnya biaya sewadan memahami aturan-aturan sewa menyewa,sekaligus melakukan negoisasi akhir dan kesepakatantransaksi sewa menyewa rumah kos sebagai tempat domisili tetap. ${ }^{24}$ Disisi lain kemudahan-kemudahan menjatuhkan dan menentukan pilihan rumah kos sebagai tempat domisili tetap, karena pada umumnya ketersediaan jumlah rumah-rumah kos, masih jauh lebih besar jumlahnya ketimbang dengan kebutuhan para konsumeris.

\footnotetext{
${ }^{23}$ Sohari Sahrani, dk, Fikih Muamalah, edisi 1, Bogor: Ghalia Indonesia, 2011, p. 173

${ }^{24}$ Afizah (Penyewa Pondok Putri Pitaloka; Mahasiswi Fakultas Saintek Jurusan Teknik Informatika UIN Suska Riau), Wawancara, Jum'at 25 Agustus 2017
} 


\section{Secara Aturan-aturan Lokalistis}

Dalam sistem sewa menyewa (al-Ijarah) pada pemanfaatan objek yang diperkirakan riskan dan rawan dengan berbagai resiko yang bakal terjadi di kemudian hari, pada umumnya seharusnya dapat dilakukan sesuai dengan aturan-aturan transaksi (perjanjian) yang dituangkan dalam bentuk tertulis yang disepakati (ditanda tangani bersama), mengatur tentang hubungan antara adanya kewajiban-kewajiban dan hak-hak masing-masing kedua belah pihak yang melakukan negoisasi dan transaksi sewa menyewa akhir. Sehingga kemashlahatan dan kepentingan bersama dapat berjalan dengan baik selama dalam masamasa sewaan berjalan, dan kalaupun terjadi atau muncul misalnya resiko-resiko di kemudian hari akan dengan mudah dapat teratasi dan diselesaikan oleh masing-masing pihak, sehingga terhindar dari tidak akan ada sepihak yang merasa dirugikan.

Dalam hal tersebut, sepanjangan pengamatan dan temuan-temuan hasil audiensi peneliti, baik terhadap para konsumeris dan produser dalam hal melakukan transaksi sewa menyewa rumah-rumah kos hanya sebatas atas dasar aturan-aturan lokalistis setelah terjadi kesepahaman dan kesepakatan sewa menyewa, itupun tidak merata pada semua rumahrumah kos yang melakukan sistem tersebut, bahkan mayoritas ditemukanmasih bebas dari sistem aturan-aturan dan tatatertib sewa menyewa secara tertulis.Menurut penuturan H.M. Nasir, S.Pd misalnya dikatakan bahwa dari beberapa lokasi rumah-rumah kos yang saya miliki, selama ini tidak pernah saya dasariaturan-aturan dan tatatertib secara tertulis yang substansinya mengatur etika-etika sosial pemanfaatan rumah kos, demikian pula yang mengatur antara adanya kewajiban-kewajiban dan hak-hak saya sebagai pemilik rumah kos dengan pihak-pihak konsumeris, melainkan selama ini hanya sematamata didasari atas kesepahaman dan kesepakatan akhir secara lisan. ${ }^{25}$ Aturan-aturan lokalistis dimaksud, adalah peraturan-peraturan dan tatatertibtertulis hitam diatas putih,baik yang dibuat oleh pihak pemilik rumah kos maupun yang dibuat oleh masing-masing para Ketua-ketua RT dan RW setempat, sebagai aturan etika dalam pemanfaatan rumah sewa dan etika bergaul dalam lingkungan domisili dan masyarakat, yang harus ditaati, dipatuhiterutama para penghuni dan pengunjung rumahrumah kos. Misalnya salah satu diantaranya "Tatatertib Pondokan Puteri Pitaloka" demi kenyamanan bersama, Pondok Putri Pitaloka

${ }^{25}$ H.M. Nasir, S.Pd (Pemilik Rumah-rumah Cost RT. 01/RW. 09), Wawancara, Senin 28 Agustus 2017, dan penuturan yang sama dari Ibu Ertin Maryati (Pemilik Rumahrumah Cost Ladis RW 10), Wawancara, Sabtu 26 Agustus 2017 
menerapkan tatatertib yang harus dihormati oleh penghuni maupun pengunjung, yaitu:

1. Menjaga ketenangan dan kenyamanan bersama dengan tidak membuat kegaduhan dan saling menghormati penghuni kos yang lain.

2. Dilarang merusak di dalam kamar, gunakan dapur umum dan menjaga kebersihan dan kenyamanan bersama dengan membersihkan dan merapikan kembali setelah menggunakan fasilitas bersama di dalam kos (dapur umum).

3. Buang sampah pada tempat yang sudah disediakan.

4. Tidak menggunakan tempat kos untuk melakukan hal-hal yang bertentangan dengan hukum dan norma-norma yang berlaku di masyarakat umum.

5. Menggunakan dan menjaga inventaris kos dengan baik dan tidak melakukan perubahan rumah kos (contohnya memaku tembok, mencoret-coret tembok dan furnitur).

6. Pengunjung/tamu pria hanya diperbolehkan ditemui di ruang tamu yang sudah disediakan.

7. Jam berkunjung maksimal pukul 22.00 (Senin-Jum'at) dan pukul 23.00 (Sabtu dan Minggu), dan pagar akan ditutup oleh penjaga.

8. Parkirlah kendaraan anda dengan rapi dan berada di dalam area kos sehingga tidak mengganggu pengguna jalan yang lain.

9. Dilarang merokok di dalam rumah kos demi kesehatan bersama.

10. Tidak menyimpan barang-barang berbahaya (senjata api, bahan mudah terbakar) dan barang-barag yang dilarang (narkoba, sabushabu dll).

11. Menghemat pemakaian air dan listrik.

\section{Dampak Etika Sosial dan Ekonomi Masyarakat}

Adanya sebagian rumah-rumah kos di wilayah Kelurahan Simpang Baru yang memberlakukan adanya aturan-aturan dan tatatertib hunian rumah kos secara insidensial, sesungguhnya pada umumnya diharapkan agar pemanfaatan rumah dapat menjadi tempat hunian yang tenteram dan damai, aman, nyaman dan bersih lingkungan serta para penghuni kos dapat bersosialisasi, bergaul dengan baik dan sopan-santun terhadap para tetangga dan masyarakat sekitar pada umumnya. Minimal adanya aturan-aturan dan tatatertibtersebut dapat maminimalisir hal-hal yang bersifat negatif dikemudian hari. Namun demikian, sepanjang pengamatan dan riset peneliti dalam realitas dan fenomena sosialnya 
tidak serta merta menjanjikan seperti apa yang menjadi harapan terutama dari pihak para pemilik rumah-rumah kos, dan para aparat Ketua-ketua RT dan RW setempat, demikian pula terhadap masyarakat pada umumnya. Terlebih-lebih rumah-rumah kos yang masih mayoritas tidak memperdulikan, bebas dari adanya yang namanya sebuah aturanauran dan tatatertib hunian. Tentu dampak-dampak sosial negatifnya akan dengan mudah dapat terjadi sekaligus dapat menodai dan merugikan tatanan kehidupan sosial masyarakat, terutama akanlebih banyak merugikan para pemilik rumah-rumah kos itu sendiri.

Salah seorang pemilik rumah kos misalnya bernama H. Nurdin Bugis berdomisili di RT 04/RW 05, dikatakan bahwa pada umumnya para penghuni rumah-rumah kos, seolah-olah tidak pernah mau tau dan peduli atas pemanfaatan rumah sebagai tempat domisili tetap, terutama dalam hal pemeliharaan berbagai fasilitas dan sampah-sampah atau kebersihan rumah dan lingkungan, sehingga pemilik rumah kos lebih banyak harus rela menanggung berbagai akibat-akibatnya. Demikian halnya dalam hal pergaulan sosial sehari-hari kadang-kadang dengan mudah muncul perilaku-perilaku sosial yang seolah-olah tidak mencerminkan sebagai pribadi-pribadi mahasiswa muslim dan mahasiswi muslimah. Terhadap masyarakat sekitar, tetangga-tetangga terdekat, jauh dari sikap-sikap rasa hormat dan tawadhu', Masjid-masjid dan Mushalla yang terdekat dari rumah kos saja tidak menjadikan perhatian untuk selalu shalat berjamaah demikian juga adanya kegiatankegiatan pengajian keagamaan dan sosial lainnya. ${ }^{26}$

Disamping itu, yang sangat lebih memperihatinkan menurut penuturan para aparat Ketua-ketua RT setempat, termasuk dalam hal ini misalnya salah seorang mantan Ketua RT 02/RW 09 bernamaH. Tarsono, SP dikatakan bahwa hampir dalam setiap tahunnya disetiap kawasan RTRT selalu muncul peristiwa-peristiwa teguran-teguran sosial, perilakuperilaku a moral dan a susila,sampai kepada tindakan-tindakan penggerebekan siang dan tengah malam terhadap penghuni kos dan tamu pengunjungditempat rumah-rumahkos pada khususnya. ${ }^{27}$ Ini menunjukkan dan memberikan kesan bahwa dengan adanya aturanaturan dan tatatertib insidensial hunian rumah-rumah kos saja tidak serta merta memberikan dampak etika sosial yang bersifat positif terhadap para penghuni dan tamu pengunjung kos terutama, terlebih-lebih

${ }^{26}$ H. Nurdin Bugis (Pemilik Rumah-rumah Cost), Wawancara, Sabtu 2 September

${ }^{27}$ H. Tarsono, SP (Mantan Ketua RT 02/RW 09 dan Pemilik Rumah-rumah Cost), Wawancara, Minggu, 3 September 2017 
bilamana rumah-rumah kosyang mayoritas terbebas dari berbagai peraturan-peraturan dan tatatertib hunian.

Selanjutnya,dari sisi dampak sosial ekonomi atas keberadaan sejumlah rumah-rumah kos sebagai salah satu lahan usaha-usaha bisnis yang dianggap sebagai investasi yang cukup menjanjikan "kata sebagian orang" dan sangat cepat trend perkembangannya di wilayah Kelurahan Simpang Baru, baik terhadap para pemilik rumah-rumah cost terutama maupun terhadap tingkat percepatan dan perkembangan kehidupan ekonomi masyarakat setempat, pada umumnya dapat dikatakankontribusinya turutmendukung dan sangat positif. Secara hitungan-hitungan bisnis baik untuk dalam jangka pendek terlebih-lebih dalam jangka panjang, bagi para pemilik rumah-rumah kos ada-ada saja yang bisa diharapkan sebagai income rutinitas dalam menunjang kelangsungan kehidupan ekonomi, meskipun harapan-harapan tersebut tidak terlalu berlebihan, karena faktor-faktor jumlah konsumeris secara terus menerus, demikian pulafaktor kondisi riil dan fisik bangunan setiap rumah-rumah kos turut sangat menentukan.

Menurut penuturan $\mathrm{H}$. Ujang Efendi selaku pemilik rumah cost, dan juga merangkap sebagai Ketua RW 09 bahwa keberadaan rumah-rumah kos yang dibangun sebagai pemanfatan dan pendayagunaan lahan-lahan tanah kaplingan, dengan harapan sebagai investasi yang dapat menghasilkan income ekonomi secara rutinitas, meskipun perolehan itu tidak terlalu semata-mata sebagai keuntungan berlebihan, karena dalam waktu-waktu tertentu terlebih-lebih dalam jangka waktu panjang, resiko-resiko krusial terhadap kondisi bangunan rumah-rumah kos, sudah pasti memerlukan sejumlah biaya-biaya perbaikan-perbaikan dan renovasi serta pemeliharaan juga. ${ }^{28}$

Sementara dampak sosial ekonominya terhadap tingkat kehidupan ekonomi masyarakat setempat, hal ini cukup sangat fenomenal dan sangat-sangat positif. Ibarat semulanya "lahan tanah-tanah kaplingan mati yang dapat menghidupkan kegiatan ekonomi masyarakat". Disekitar setiap rumah-rumah kos setempat, berkembang berbagai jenis usaha-usaha bisnis, yang pada umumnya dikelola oleh penduduk masyarakat setempat maupun dari kalangan luar, bahkan dari kalangan para mahasiswa itu sendiri. Semua jenis-jenis usaha bisnis, mulai dari rumah-rumah makan dan kedai-kedai minuman, ruko-ruko photo copi, printer dan buku, cetak dan jilid buku-buku serta skripsi, studio photo, pakaian dan jilbab, loundry, servis dan jual beli Hp serta pulsa, tempat-

${ }^{28}$ H. Ujang Efendi (Pemilik Rumah Cost dan Ketua RW 09 Kelurahan Simpang Baru), Wawancara, Minggu 1 Oktober 2017 
tempat cucian roda dua, demikian pula swalayan-swalayan mini, sampai kepada berbagai jenis usaha bisnis makanan, kue-kue dan minuman ringan, serta buah-buahan di sekitar sudut rumah dan pinggir-pinggir jalan. Semuanya itu, merupakan sarana-sarana ekonomis yang pada umumnya sangat membantu menyangkut masalah keperluan dan kebutuhan sehari-hari terutama dari kalangan para mahasiswa dan mahasiswi dari berbagai latar belakang Perguruan Tinggi, yang pada gilirannya sangat mempengaruhi tingkat perputaran ekonomi, percepatan dan peningkatan taraf kehidupan sosial ekonomi masyarakat secara keseluruhan. ${ }^{29}$

\section{D.Sewa Menyewa Rumah Kosdalam Perspektik Hukum Ekonomi Syariah}

Gambaran sistem sewa menyewa rumah-rumah kos di wilayah Kelurahan Simpang Baru, sudah dapat dipahami dari apa yang telah dikemukakan di atas. Berikut ini, ada beberapa hal yang menjadi pehatian bahasan dan tinjauan dalam perspektif hukum ekonomi syariah, ${ }^{30}$ sebagai jawaban dari substansi hasil penelitian ini, yaitu sebagai berikut:

\section{Sisi Pemasaran dengan Promosi Sosial}

Istilah pemasaran dalam dunia usaha bisnis dapat diartikan sebagai suatu proses sosial yang merancang dan menawarkan sesuatu yang menjadi hajat (kebutuhan) dan keinginan dari para konsumeris (pelanggan) dalam rangka memberikan kepuasan yang optimal kepada pelanggan. Dalam hal tersebut,banyak cara yang dapat dilakukan dalam proses, tergantung sistem

${ }^{29}$ Observasi Beberapa Lokasi Rumah-rumah Cost disetiap RT/RW Kelurahan Simpang Baru, Minggu 5 Oktober 2017

${ }^{30}$ Karena sebagai seorang muslim seharusnya berusaha keras menjadikan muamalahnya sebagai amal shaleh dan ikhlas untuk Allah semata. Memahami/mengetahui hukum muamalah amaliyah wajib bagi setiap muslim, namun untuk menjadi expert (ahli) dalam bidang ini hukumnya adalah fardhu kifayah.Oleh karena itu Khalifah Umar bin al-Khatthab, disaat senantiasa melakukan sweping, berkeliling di pasar, ia berkata tidak boleh bermuamalah (jual beli) di pasar kita kecuali orang yang benar-benar telah mengerti fiqh (muamalah) dalam agama Islam. Dari ucapan tersebut dapat dijabarkan lebih lanjut bahwa setiap warga masyarakat Islam, antara lain: tidak boleh beraktivitas bisnis, berdagang kecuali paham tentang fiqh muamalah, tidak boleh beraktivitas perbankan, asuransi, pasar modal, koperasi, pegadaian, reksadana dan bisnis MLM kecuali paham fiqh mamalah, tidak boleh beraktivitas jual beli, sewa menyewa dan aktivitas apa pun kecuali paham fiqh muamalah. Menunjukkan kata $A b d u l$ Sattar bahwa muamalah adalah inti terdalam dari tujuan agama Islam untuk mewujudkan kemashlahatan kehidupan manusia. Karena itu, para Rasul terdahulu mengajak umat (berdakwah) untuk mengamalkan muamalah, karena memandangnya sebagai ajaran agama yang mesti dilaksanakan, tidak ada pilihan bagi seseorang untuk tidak mengamalkannya. Baca, Zainuddin Ali, Hukum Ekonomi Syariah, edisi 1, Jakarta: Sinar Grafika, 2008, p. 122-123 
strategi promosi yang digunakan. Dalam Islamic Marketing seluruh proses, baik proses penciptaan, proses penawaran maupun proses perubahan nilai, tidakboleh ada hal-hal yang bertentangan dengan akad dan prinsp-prinsip muamalah Islami, maka bentuk transaksi sosial apapun dalam marketing diperbolehkan. ${ }^{31}$ Hal tersebut sesuai maksud dalam salah satu Firman Allah swt surah Shaad ayat 24, bahwa dalam bermuamalah kita dilarang keras untuk berbuat kezdaliman. Demikian pula dalam salah satu kaidah fiqih, dikatakan bahwa "asal sesuatu adalah boleh sampai ada dalil (argumentasi sahih) yang menunjukkan keharamannya". Dalam artian bahwa pemasaran dalam bentuk promosi sosial merupakan salah satu bentuk muamalah yang dibenarkan dalam Islam, sepanjang dalam segala proses cara-cara dan transaksinya terpelihara dari hal-hal yang terlarang oleh ketentuan syariah. ${ }^{32}$

Sistem pemasaran rumah-rumah kos di wilayah Kelurahan Simpang Baru dengan melalui promosi-promosi sosial, baik secara insidensial (personal selling) dan maupun secara media sosial (advertising, publisitas) sebagaimana telah dikemukakan, pada umumnya dapat dikatakan ada sisi-sisi relevansinya dengan muamalah dalam sistem hukum ekonomi syariah. Karena cara-cara atau strategi yang diupayakan para pemilik dan petugas rumah-rumah kosdalam rangka menarik minat dan perhatian mendalam para calon-calon konsumeris, terutama dari kalangan mahasiswa dan calon-calon mahasiswa-mahasiswi, mengandung unsur-unsur shiddiq dalam artian ada proses kejujuran yang selalu melandasi ucapan, keyakinan, serta perbuatan, ada unsur-unsur amanah dalam artian ada proses tampilan serba keterbukaan, serta pelayanan prima dan ihsan, serta ada unsur-unsur tabligh dalam artian bahwa dalam proses memberikan informasi penuh dengan hikmah (non paksaaan), tabah dan sabar, argumentatif dan persuasif menumbuhkan hubungan kemanusiaan yang solid, sehingga dengan mudah mengundang para konsumeris menjadi penghuni tetap rumah kos. ${ }^{33}$

2. Sisi Aturan-aturan Perjanjian

Syariat Islam mengajarkan kepada manusia agar menjalankan segala aktivitasnya berdasarkan aturan-aturan yang telah ditentukan oleh Allah Swt dan Rasulnya. Begitupun dalam menjalankanberbagai kegiatan muamalah, hendaknya berdasarkan tatacara yang baik dan diridhai oleh Allah Swt.

${ }^{31}$ Veithzal Rivai, Islamic Marketing, Jakarta: PT. Gramedia Pustaka Utama, 2012, p. p. $26-27$

${ }^{32}$ Imam Musbikin, Qawa'id al-Fiqhiyyah, Jakarta: PT. Raja Grafindo Persada, 2001, p. $25 \mathrm{dst}$.

${ }^{33}$ M. Nur Rianto, Dasar-dasar Pemasaran Bank Syari'ah, Bandung: Alfabeta, 2010, 
Demikian halnya khususnya dalam kegiatan sistem sewa menyewa rumahrumah kos, idealnya harus senantiasa teriringi dengan adanya peraturanperaturan transaksi yang jelas dan tertulis (QS. 2 : 282), baik menyangkut aturan-aturan etika sosial, maupun aturan-aturan perjanjian yang mengatur hubungan antara kewajiban-kewajiban dan hak-hak secara timbal balik. Sehingga adanya ikatan yang kuat antara dua orang atau lebih di dalam bertransaksi atau memiliki sesuatu, dan tidak dapat sembarangan dalam membatalkan suatu ikatan perjanjian, karena telah diatur secara syar'i, serta bukankah akad (perjanjian) merupakan payung hukum di dalam kepemilikan dan kemanfaatan sesuatu, sehingga pihak lain tidak leluasa dapat menggugat, memilikinya atau memanfaatkannya. ${ }^{34}$

Sesungguhnya sistem sewa menyewa rumah-rumah kos di wilayah Kelurahan Simpang Baru, tetap didasari adanya aturan-aturan, hanya saja baru sebatas aturan-aturan dan tatatertib yang mengatur pemanfaatan berbagai fasilitas rumah kos, serta etika sosial para penghuni dan pengunjung, baik yang diadakan oleh pemilik rumah (lisan atau tertulis) maupun yang diadakan oleh masing-masing Ketua RT dan RWsetempat secara tertulis. Itupun tidak merata melainkan hanya minoritas ditemukan jumlah rumah-rumah kos yang dapat menerapkan sistem tersebut. Hasil yang diharapkan pun dari tujuan aturanaturan tersebut, juga tidak efektif hasilnya. Terlebih-lebih lagi, tidak ditemukan yang menerapkan dalam bentuk aturan-aturan perjanjian tertulis sewa menyewa, yang khusus mengatur adanya hubungan kewajiban-kewajiban dan hak-hak antara pemilik rumah kos dengan para penyewa. Sehingga dari segi tujuan dan efektifitas dalam hal sewa menyewa rumah-rumah kos dalam perspektif hukum ekonomi syari'ah, dapat dikatakan belum sesuai dan belum menjamin sebagaimana apa yang diharapkan oleh semua pihak dalam lingkungan kehidupan bermasyarakat. Bahkan sangat boleh jadi berbagai resiko sosialyang muncul dikemudian hari dalam hal sewa menyewa tersebut, lebih banyak harus ditanggung sepihak oleh pihak pemilik rumah-rumah kos itu sendiri.

Pemanfaatan rumah-rumah kosyang rentan dengan segala problematika dan resiko-resiko sosialnya tanpa diikat dengan aturan-aturan yang jelas, yang dalam sistem hukum ekonomi syariah dikenal dengan istilah akad musamma kategori akad al-tamlikiyyah dan akad al-mu'awwadah, ${ }^{35}$ maka tidak banyak

\footnotetext{
${ }^{34}$ Abdul Rahman Ghazaly, dkk, Fiqh Muamalat, edisi 3, Jakarta: Prenada Media Group,2015, p. 59

${ }^{35}$ Merupakan salah satu jenis akad yang disebutkan oleh syara' dengan terminologi tertentu beserta akibat-akibat hukumnya. Dalam proses merupakan akad kategori yang dimaksudkan sebagai proses pemilikan, baik pemilikan benda maupun pemilikan manfaat, dimana konsekuensi akad dilakasanakan dengan saling memberi dan menerima oleh kedua
} 
yang dapat diharapkan perubahan yang namanya sebuahamanah menjadi tanggungjawab, apabila terjadi hal-hal berikut:

a. Pihak penyewa (ajir) tidak menjaga barang (fasilitas dan manfaat rumah cost) dengan baik. Dalam hal ini apabila barang tersebut rusak, maka ia (ajir) wajib menggantinya.

b. Pihak penyewa (ajir) melakukan perbuatan yang merusak barang dengan sengaja. Dalam hal ini ajir, baik khas (sendiri) maupun musytarak (bersama) wajib mengganti barang yang dirusaknya itu. Apabila kerusakan barang bukan karena kesengajaan, dan hal tersebut dilakukan oleh ajir khas maka para ulama sepakat tidak ada penggantian kerugian. Akan tetapi, apabila hal itu dilakukan oleh ajir musytarak, menurut Abu Hanifah, ia harus mengganti kerugian. Sedangkan menurut syafi'iyyah, ajir tidak dibebani ganti kerugian, selama bukan karena kelalaian atau bukan karena kesengajaan. ${ }^{36}$

\section{Sisi Dampak Kemashlahatan}

Keberadaan rumah-rumah kos sebagai salah satu usaha-usaha bisnis yang diharapkan punya kontribusi dalam rangka memfasilitasi kebutuhan-kebutuhan para konsumeris (khususnya mahasiswa dan mahasiswi), merupakan bagian perwujudan dari pada fungsi manusia sebagai khlifah fil ardh. Kekhalifahan manusia di muka bumi, hal itu mengandung dua dimensi pokok jika dibandingkan peran dan tugas para malaikat. ${ }^{37}$ Pertama, tugas kekhalifahan itu mengusung misi perpanjangan tangan Allah ke bumi. Manusia sebagai mandataris kekhalifahan harus melaksakan tugas sesuai yang diamanatkan-Nya, khususnya tugas penghambaan (pengabdian) langsung kepada Allah, seperti halnya malaikat. Kedua, tugas kekhalifahan juga bermakna pemberian otonomi khusus kepada manusia dalam rangka memakmurkan dunia sesuai prinsip pemberi kuasa (Allah Swt), beserta segenap kewenangan dan kebebasan yang diberikan kepadanya. Pada tugas ini, Allah memberikan peran kepada manusia melebihi tugas para malaikat yang tidak diberikan kewenangan dan kebebasan khusus. Peran tersebut adalah selain manusia memiliki tugas (ibadah) sebagaimana malaikat, juga mendapatkan tugas sebagai pemimpin dunia yang

belah pihak. Baca, Ghufron A.Mas'adi, Fiqh Muamalh Kontekstual, edisi 1, Jakarta: PT. Raja Grafindo persada, 2002, p.107

${ }^{36}$ Ahmad Wardi Muslich, Fiqh Muamalat, edisi 1, Jakarta: Amzah, 2010, p. 335

${ }^{37}$ M. Arfin Hamid, Hukum Ekonomi Islam (Ekonomi Syariah) Di Indonesia, Aplikasi \& Prospektifnya, edisi 1, Bogor: Ghalia Indonesia, 2007, p. 39 
diberikan kewenangan khusus dengan sasaran akhir, yaitu agar senantiasa menciptakan kemakmuran di bumi. ${ }^{38}$

Tersedia dan tercukupinya kebutuhan-kebutuhan sosial masyarakat yang akan memberikan dampak yang disebut dengan mashalahah yaitu segala bentuk keadaan, kebutuhan-kebutuhan masyarakat baik yang bersifat meterial maupun nonmaterial, yang mampu meningkatkan kedudukan dan martabat manusia sebagai makhluk yang paling mulia (QS. $95: 4) .^{39}$

Dengan demikian, sebagai pengusaha bisnis dan pemilik rumah-rumah cost dalam rangka upaya memenuhi tuntutan kebutuhan-kebutuhan masyarakat atau tujuan produksi itu sendiri secara umum (QS. $11:$ 61) adalah semata-mata untuk mencapai kemashlahatan al-falah (kesuksesan dan kebahagiaan) hakiki, yaitu:

a. Memenuhi kewajiban sebagai khalifah di bumi, beribadah kepada Allah dan untuk menjalankan fungsi sosial.

b. Untuk memenuhi kebutuhan hidup pribadi dan keluarga

c. Sarana untuk memenuhi kebutuhan masyarakat akan barang dan jasa secara umum, dan

d. Sebagai persediaan untuk generasi di masa yang akan datang (QS. 59 : 18). ${ }^{40}$

Para pengusaha bisnis dan pemilik rumah-rumah kos diwilayah Kelurahan Simpang Baru, sebenarnya apa yang dilakukan serta kontribusinya selama ini sudah merupakan bagian dari sistem hukum ekonomi syariah. Sebagaimana dipahami bahwa keberadaan rumah-rumah kos, dampak sosial ekonominya terhadap khususnya perkembangan tingkat kehidupan sosial ekonomi masyarakat setempat, cukup mewarnai nilai-nilai kemashalahatan. Para konsumeris dengan mudah menikmati hunian rumah-rumah kos, dan masyarakat sekitar setiap tempat rumah-rumah kos dengan mudah juga mewujudkan berbagai jenis usaha-usaha bisnis lainnya, yang pada akhirnya sangat menunjang akan berbagai keperluan dan kebutuhan-kebutuhan demi kelangsungan hidup, bahkan yang namanya status sosial ekonomi masyarakat setempat, dapat dipastikan secara fenomenal sosial menunjukan semakin mengalami peningkatan dan perkembangan yang signifikan. Demikian halnya terhadap para pengusaha bisnis dan para pemilik rumah-rumah kos, dalam

\footnotetext{
${ }^{38}$ Ibid

${ }^{39}$ Pusat Pengkajian dan Pengembangan Ekoomi Islam (P3EI) UII Yogyakarta kerja sama dengan Bank Indonesia, Ekonomi Islam, edisi 1, Jakarta: PT. Raja Grafindo Persada, 2008, p. 5

${ }^{40}$ Mohammad Hidayat, An Introduction to The Sharia Economic, Pengantar Ekonomi Syariah, Jakarta: Zikrul Hakim, 2010, p. 219
} 
kondisi tertentu sangat boleh jadi dapat dikatakan akan memperoleh keuntungan investasi terutama dalam waktu jangka panjang.

\section{E. Simpulan}

Beberapa kesimpulan yang dapat peneliti kemukakan sebagai akhir bahasan yang berkenaan dengan sistem sewa menyewa rumah-rumah kos di wilayah Kelurahan Simpang Baru Kecamaan Tampan Kota Pekabaru dalam perspektif hukum ekonomi syariah, yaitu sebagai berikut:

1. Maraknya perkembangan keberadaan berbagai tipe dan model rumahrumah kos di wilayah Kelurahan Simpang Baru dalam 10 tahun terakhir ini, disamping dipengaruhi oleh lokasi daerah yang sangat strategis, juga munculnya para pengusaha bisnis dari luar daerah, seiring dengan usaha-usaha yang dilakukan oleh penduduk masyarakat setempat. Proses pembangunannya sejak dari awal, baik yang dibangun oleh para pengusaha bisnis dari luar daerah terutama,dalam bentuknya lux dan super lux bertingkat, maupun dalam bentuk lainnya yang mayoritas dibangun oleh penduduk masyarakat setempat, pada umumnya belum memenuhi syarat prosedural seiring dengan adanya peraturan-peraturan yang berlaku.

2. Sistem pemasaran rumah-rumah kos dengan melalui promosi-promosi sosial insidensial dan media sosial, dengan mudah menarik perhatian dan minat para konsumeris terutama dari kalangan mahasiswa dan calon-calon mahasiswa dan mahasiswi dalam setiap tahunnya, ada sisisisi relevansinya dengan muamalah dalam sistem hukum ekonomi syariah.

3. Aturan-aturan jelas dan tertulis yang mengatur hubungan adanya kewajiban-kewajiban dan hak-hak antara pihak-pihak yang melakukan transaksi sewa menyewa rumah-rumah kos, belum menjadikan suatu prinsip seharusnya, sehingga bilamana muncul dikemudian hari berbagai resiko, misalnya; rusaknya pintu dan pintu-pintu kamar, rusaknya pintu-pintu jendela setiap kamar, rusaknya pintu kamar mandi dan wc, dan rusaknya mesin pompa air, putusnya setiap bola lampu, serta terjadinya musibah kebakaran karena kelalaian memasak, maka pihak pemilik rumah kosyang selalu menanggung semua resiko tersebut karena dianggap lebih bertanggung jawab. Disamping itu, meskipun adanya aturan-aturan atas dasar aturan-aturan etika sosial dalam pemanfaatan rumah-rumah kos dengan masyarakat setempat, baik secara lisan dan tertulis yang dibuat oleh sebagian pemilik rumah-rumah kos, maupun yang dibuat secara resmi tertulis oleh sebagian Ketua- 
ketua RT dan RW setempat, pada umumnya belum menjanjikan sasaran dan tujuan yang efektif dalam sistem sewa menyewa rumah-rumah kos.

4. Semarak Keberadaan dan kontribusi rumah-rumah kos diwilayah Kelurahan Simpang Baru, disisi sosial ekonomi cukup memberikan dampak al-Falah dan al-Mashlahah yang sangat positif pada berbagai kalangan, menyebabkan taraf hidup dan kehidupan ekonomi masyarakat setempat mengalami peningkatan yang pesat dan signifikan. Dalam kondisi seperti itu, dilain sisi maka sistem sewa menyewa rumah-rumah kos di wilayah Kelurahan Simpang Baru dapat dikatakan relevan dengan sewa menyewa dalam sistem hukum ekonomi syariah itu sendiri.

\section{DAFTAR PUSTAKA}

Abdullah Abdul Husain at-Tariqi, Al-Iqtishad al-Islai Ushusun wa Mubaun wa akhdaf,edisi 1, terjemahan M. Irfan Syofwani,Yogyakarta: Magistra Insania Press, 2004

Abdul Rahman Ghazaly, dkk, Fiqh Muamalat, edisi 3, Jakarta: Prenada Media Group, 2015

Abdul Ghofur Anshori, Hukum Perjanjian Islam di Indonesia, te, Yogyakarta: Gajah Mada University Press, 2010

Abdul Hamid Mursi SDM Yang Produktif, Pendekatan al-Quran dan Sains, edisi 1, terjemahan Moh. Nurhakim, Jakarta: Gema Insani Press, 1977

Afzal al-Rahman, Doktin Ekonomi Islam, Jilid 3, edisi 2, terjemahan Mustafa Kassim, Kuala Lumpur: Dewan Bahasa dan Pustaka Kementerian Pendidikan Malaysia, 1994

Ahmad Ibrahim Abu Sinn, Manajemen Syariah sebuah Kajian Historis dan Kontemporer,terjemahan Dimyauddin Djuwaini, edisi 1, Jakarta: PT. Raja Grafindo Persada, 2008

Ahmad Wardi Muslich, Fiqh Muamalat, edisi 1, Jakarta: Amzah, 2010

Amir Syarifuddin, Garis-garis Besar Fiqih, edisi 2, Jakarta: PT.Prenada Media Group, 2003

Arfin Hamid, Hukum Ekonomi Islam (Ekonomi Syariah) di Indonesia, Aplikasi dan Prospektifnya, edisi 1, Bogor: Ghalia Indonesia, 2007

Ernie Tisnawati Sule dk, Pengantar Manajemen, edisi 1, Jakarta: Prenada Media, 2005

Ghufron A.Mas'adi, Fiqh Muamalah Kontkestual, edisi 1, Jakarta: PT. Raja Grafindo Persada, 2002

Hamzah Ya'qub, Kode Etik Dagang Menurut Islam, edisi 1, Bandung: CV. Diponegoro, 1984 
Hendi Suhendi, Fiqih Muamalah, edisi 1, Jakarta: PT. Raja Grafindo Persada, 2002

Idri, Hadis Ekonomi, edisi 1, Jakarta: Prenada Media Group, 2015

Imam Musbikin, Qawa’id Al-Fiqhiyyah, Jakarta: PT. Raja Grafindo Persada, 2001

M. Nur Rianto, Dasar-dasar Pemasaran Bank Syari'ah,Bandung: Alfabeta, 2010

Pustaka, 2007

M. Quraish Shihab, Wawasan Al-Quran, edisi 1, Bandung: PT. Mizan M. Thalib, Fiqih Nabawi, edisi 2, Surabaya: al-Ikhlas, tt

Muhammad ibn Ibrahim ibn Abdullah, Mausu'ah al-Fiqh al-Islam, Jilid 3, tp, (tanpa tahun)

M.Yatimin Abdullah, Pengantar Studi Etika, edisi1, Jakarta: PT. Raja Grafindo Persada, 2006

Mohammad Hidayat, An Introduction to The Sharia Economic, Pengantar Ekonomi Syariah, Jakarta: Zikrul Hakim, 2010

Pusat Pengkajian dan Pegembangan Ekonomi Islam UII Yogyakarta atas Kerjasama dengan Bank Indonesia, Ekonomi Islam, edisi 1, Jakarta: PT. Raja Grafindo Persada 2008

Ronny Hanitijo Soemitro, Metodologi Penelitian Hukum, edisi 1, Jakarta: Ghalia Indonesia, 1983

Saleh Al-Fauzan, Fiqih Sehari-hari, edisi 2, Jakarta: Gema Insani, 2005 Syeikh Mahmuod Syaltout, Al-Islam 'Aqidah wa Syariah, Jilid IV, terjemahan Bustami A.Gani, dk, Jakarta: Bulan Bintang, 1970

Soerjono Soekanto, Pokok-pokok Sosiologi Hukum, edisi 4, Jakarta: CV. Rajawali, 1987

Sohari Sahrani, dk, Fikih Muamalah, edisi 1, Bogor: Ghalia Indonesia, 2011

Veithzal Rivai, Islamic Marketing, Jakarta: PT. Gramedia Pustaka Utama, 2012

Wahbahal-Zuhaily, Al-Fiqh al-Islam wa 'Adillatuhu, Jilid V, edisi 8, Damaskus: Daar al-Fikr al-Mu'assim, 2005

Zainuddin Ali, Hukum Ekonomi Syariah, edisi 1, Jakarta: PT. Raja Grafindo Persada, 2008 